NILS G. HOLM

\title{
Mysticism and Spirituality
}

\section{Introduction}

Since my active period as professor is coming to an end, this might be a good time to make a brief survey of some of my interests and research activities, which are in line with the main topic of the Donner Institute's conference on postmodern spirituality. First of all, I wish to note that, to a large extent, I have focussed on popular phenomena of an experiential character. Therefore I have specialised in questions pertaining to the psychology of religion, since this field has provided explanations for the religious phenomena that I have been interested in.

But how does the popular correspond to the grand terms of the title? Are not mysticism and spirituality something very exclusive, reserved for a few individuals? I do not think so. The following presentation of both my own studies and the research of others will provide a different picture of these two concepts.

Mysticism and spirituality are notions that are very difficult to define. Traditionally mysticism has been regarded as a way to reach the inner dimensions of human life, dimensions where man even achieves unity with the Divine Being. Such traditions have been found in all the major religions, and since the times of William James a hundred years ago, the features of mysticism in various religions have been analysed.

Spirituality is a concept that can hold various meanings. It has often been associated with religious traditions where inner life and its growth are emphasized. These include, in particular, various schools, orders and movements that aim at cultivating a deeper spiritual life. In its more recent use, the term spirituality has, to a fairly large extent, been dissociated from religion and has become a notion that seeks to grasp the searching of modern man for ethics and norms in a globalised world, where pollution is accelerating and where stress and entertainment disrupt the inner harmony of people. I will return to these issues later on in this article. 


\section{My research on Pentecostalism}

My early research in the beginning of the 1970 aimed at exploring Pentecostalism from as comprehensive a perspective as possible. I was particularly interested in the individual experiences, primarily the speaking in tongues and baptism in the Holy Spirit. My licentiate thesis 1973 (published 1974) was a linguistic study of the actual production of sound in glossolalia. I recorded an extensive amount of field material and then started the laborious work of analysing the speaking of tongues on the tapes. Counting sounds in the glossolalia, comparing these to phenomena in ordinary languages and drawing conclusions on sound qualities in tongue-speaking was a very demanding task. My results showed that the glossolalia mainly consisted of sound forms from the speaker's mother tongue, but these were expressed in simplified patterns. Sometimes, however, more exotic sounds found in foreign languages were added. (Holm 1974 and 1975.)

My subsequent project was my doctoral thesis (1976), with the objective to explain the actual experiences of spiritual baptism among the Pentecostalists. On the basis of a large body of empirical material, I could draw the conclusion that baptism in the Holy Spirit was a kind of role-play, where the participants took on models from actual examples in the congregations, but, above, all, from the holy tradition, that is, from the Bible. After a transition period when a person is waiting to be spiritually baptized, he or she takes on a role as 'the one that God has given an abundant measure of the Holy Spirit. The rite of passage usually begins with the person starting to speak in tongues, in preparation for taking on the entire role (Holm 1978).

Thus, my research has shown that speaking in tongues can be regarded as a common human skill, which we all are able of, if the social and psychological obstacles to speaking mumbo jumbo are removed. Such obstacles are removed within Pentecostalism when glossolalia is connected to the role of spiritual baptism, and people often, during prayer in the congregation or when going to bed at home, reach a stage where the ability to speak in tongues emerges. This greatly excites the person.

\section{My research on mysticism}

The glossolalia research led me to further questions on ecstasy and mysticism. At the end of the 1970 I therefore started an extensive empirical project together with a number of psychology students. We explored strong personal 
experiences among ordinary people in Swedish Finland. In this, I made great use of the research carried out by Ralph W. Hood in the USA. Having gained permission, I translated his test into Swedish, and the psychology students distributed it together with an interview and a questionnaire. The material was partly analysed by the participants in the course, but above all, by myself. This work resulted in the book Mystik och intensiva upplevelser (Mysticism and Intensive Experiences, 1979). The main results were also published elsewhere, for example in Journal for Scientific Study of Religion (Holm 1982b).

In the book, I first give an extensive presentation of research on mysticism in the twentieth century. I noted that there were various approaches to the research and that much was based on the main representative of American psychology or religion from a hundred years back, William James. There was also an emerging line of research on yoga and meditation, and the use of drugs. However, much remained to be done. The empirical research, then represented by Hood, was something entirely new and interesting in this context. For me, it was of great advantage to be able to continue his research contributions. Our results also matched each other well. Above all, we could note that ordinary people have strong experiences with qualities that to a fair extent also correspond to those described in the so-called great mystics within the world religions. The criteria we used to narrow down mysticism were based on W. T. Stace's categorization of reports and descriptions given by the great mystics over several centuries.

As it happened, the Donner Institute organised a conference in Åbo in August 1981 on the topic of Religious Ecstasy. I then got the opportunity to present my glossolalia research and also give a survey of the research on ecstasy. This survey (Holm 1982a) is the introduction of the volume published after the conference, number XI in the series Scripta Instituti Donneriani Aboensis, 1982.

At the end of that article, I emphasized that there were some important research tasks that rapidly needed some input. These were, for example, 'continued research into the nature, origin and properties of the mental state itself, particularly in relation to hypnosis' and 'studies of culture-bound models of altered states of consciousness'. In addition, I pointed to sociological and psychological questions pertaining to the issue.

I concluded the article by underlining the need for research into human neurological structures in order to gain greater insights into ecstasy and mysticism. I also wrote the following: ‘. . man has a basic capacity to condense his needs, desires and religions of various kinds into symbolic form' (Holm 1982a: 24). 
What I then wrote, on the need for research pertaining to ecstasy and mysticism, can be summarised in the following points. Firstly, I called for studies on the mental states as such, apart from research directly concerned with the cultural expressions of mysticism and ecstasy. Here, hypnosis research was an obvious gateway at that time. It is important to explore the neurological structures on a basic, biological level. Secondly, mysticism should be placed in a cultural context, and the interaction between biology and social psychology explored. And thirdly, I postulate that human beings have a capacity to translate their needs and wishes into a symbolic form of the kind represented by religion. In the following, I will give a few glimpses of studies pertaining to mysticism and intensive experiences.

\section{Later research on mysticism}

Research into mysticism has developed during the last decades. I myself have not had the opportunity to pursue these issues to any greater extent. Looking at the field, we find studies using approaches from the philosophy of religion and studies focussing on the psychology of religion. Naturally, there are also descriptions of the intensive mystic experiences of individuals within various religions. Accounts of meditation, yoga and the dimensions of inner life are always interesting to us.

The point of departure for the interest in the philosophy of religion has, to a very large extent, been William James and his classic presentations in the famous lectures The Varieties of Religious Experience. In this context, I only want to refer to Eugene Taylor's, William James on Exceptional Mental States (1983), Richard H. Jones', Mysticism Examined. Philosophical Inquiries into Mysticism (1993) and G. William Barnard's, Exploring Unseen Worlds. William James and the Philosophy of Mysticism (1997). Research on mysticism with a philosophical approach is also carried out at the Lund University in Sweden. I am primarily thinking of Catharina Stenqvist (1984 and 1994) and Christina Runqvist (2002). There are much more work that could be mentioned, but I am letting this suffice here.

Within Nordic research on the psychology of religion, Antoon Geels in Lund can be particularly emphasized. Using approaches from the psychology of religion, he has presented extensive descriptions of mysticism, in the main religions (see Geels 2002). His work has given those of us within the Swedish language area a comprehensive and deepened understanding of mysticism. Geels has also focused on persons with mystic experiences in modern times. 
The experimental psychological research has been continued particularly by Ralph W. Hood in the USA. As has already been mentioned, he is interested in contemporary strong human experiences. In this context, I wish to refer to his article 'The Common Core Thesis in the Study of Mysticism' (2006), where he argues that mysticism exists as an element within religions, but also in individuals without a strong religious profile.

\section{Cognitive research}

Since I wrote about neurological structures, research pertaining to basic biological functions has been strongly accentuated. Personally, I have not actively participated in this line of research, but it has been interesting to follow what has been written within the field.

One area of research on religion has, in a strange way, slid over to trying to discover the biological bases for linguistic communication and thus also for religion (Andresen 2001). Leading figures in this field of research include Dan Sperber, Pascal Boyer, Harvey Whitehouse, Robert N. McCauley, E. T. Lawson and Ilkka Pyysiäinen (see Whitehouse \& McCauley 2005). In several extensive studies these scholars argue for the biological foundation, that is, the human cognitive developmental basis, for communication of a religious kind. Here, I cannot refer to studies done in this field, since it would simply take too long. However, I wish to point out that there has occurred, in this area, an interesting repetition of the thoughts and attitudes held about one hundred years ago. The theory of evolution was then high fashion, and religions and cultures were also included in the models. In the middle of the last century, and particularly after the horrors of the Second World War, cultural evolutionism was strongly criticized. Instead, issues of social constructivism were emphasized within research. The behaviour of individuals were thus to be understood exclusively on the basis of culture and environment.

I welcome the renewed interest in the cognitive basis in many respects. It is important that we get research aiming at exploring the fundamental biological functions that govern our behaviour, emotions and thoughts. However, when scholars of religion with a background in the humanities venture into fields designed by the natural sciences, there is a risk of over-interpretation and even of misunderstanding the results of neuro-psychologists. I am not at all saying that this would pertain to every form of cognitive research on religion, but I seem to have noted a somewhat vague basis for some of the cognitively oriented conclusions. Much of it is close to what could be called speculation. 
Too narrow a cognitive interpretation of religious phenomena is perhaps a disappearing trend in more recent studies of this kind. As an example I would here like to mention Ilkka Pyysiäinen's article 'Amazing Grace: Religion and the Evolution of the Human Mind' (2006). In his conclusion, Pyysiäinen writes the following: 'Religion is a specific kind of human activity canalized by cognitive process with an evolutionary background' (Pyysiäinen 2006: 221). This sounds perfectly self-evident, and he continues: 'Although not an adaptation in itself, religion yet is a cultural institution that has transformed the evolutionary process. We have had to adapt to a cultural environment shaped by religion because our ancestors have imitated learned patterns of behavior... The spread of religion is due to gene-culture coevolution rather than to straightforward biological adaptation.' (Pyysiäinen 2006: 221). In other words, Pyysiäinen here clearly calls for research on religion that takes both biology and culture into consideration. There must, thus, be a balance in research, and, at the same time, space must be allowed for studies within limited special areas, too. Socio-psychological approaches and a focus on the psyche and the body can, together, provide a fuller picture of certain phenomena. Nevertheless, the mental and neurological foundations have not yet been entirely described. Much remains to be done pertaining to neurobiology. But this is perhaps, after all, a task primarily for neuropsychologists and not for scholars of religion with only a humanist or theological education. In order to understand the whole phenomenon of religion, forms of culture also hold an essential meaning, and this field is better suited for scholars of culture and religion.

\section{Spirituality}

Another important line of research that has developed since I wrote my summary in the beginning of the 1980 s, is research pertaining to spirituality. There are several approaches to this field, but I choose to emphasize here the studies and influence of $\mathrm{H}$. Gardner. His point of departure is intelligence research, and in his theory he identifies seven different forms of intelligence. He also postulates an intelligence that can be called spiritual. In other words, individuals can display a form of spirituality in the same way as they can show intelligence.

On the basis of this theoretical framework, research within education has been developed. Here, Finnish education researchers are at the forefront. In Helsinki, Kirsi Tirri (2004) leads a project aiming at exploring the connec- 
tions between intelligence and spirituality. The universe and conditions of life are issues that attract some young people to formulate a kind of general spirituality. Humans are thus disposed to experience and see the world in a way that can be called spiritual. In the educational context in schools, the teaching of religion should therefore associate to such basic spiritual needs of the pupils in order for the teaching to be successful (Ubani 2007).

The concept of spirituality has, during recent years, been introduced as a term for all the interest in meditation, yoga, tranquillity and personal growth that has emerged on the general cultural level. This began a few decades ago with what was usually called New Age and was a loose combination of interests in human spiritual dimensions. The term New Age has now been abandoned and we are left with spirituality. We have thus, in our Scandinavian languages, got a new meaning and use for this word. It aims at capturing the interest in personality developing psychological mechanisms beyond what is traditionally called religion. Religion is regarded as something more or less rigid and static, something antiquated and unnecessary. On the other hand, the individual need for spiritual development is seen as something positive, and answers to this are sought in movements originating in China and India. I am thinking of, for example, Feng Shui and various forms of meditation with roots in Hinduism or Buddhism. A good portion of imaginative thoughts and notions tend to be associated with this interest. Studies focussing on esotericism and occultism seek to capture some of all this.

So, research on religion today does not only comprise studying what we traditionally understand as religions, but must also consider all spirituality besides the religions. It is therefore interesting to note that what I, in my mysticism research in the 1970s, could formulate as general mysticism, something found in ordinary people, is very close to what is today called spirituality. Ralph W. Hood draws more or less the same conclusion in his article 'The Common Core Thesis in the Study of Mysticism' from 2006, which I referred to above. In other words, there is a field of experience in people that is inclined towards mysticism and intensive experiences, and which is brought to the fore in many tangible ways in our culture today. People 'see the light' but not in the same manner as before. The issue for research is to explore this with regard to biological as well as cultural models. The interaction of nature and culture on a personal level is also an important topic to be studied. 


\section{The understanding of symbols}

The third point in my summary of research tasks from more than 25 years ago pertains to symbols. About 15 years later, in a commissioned article on the role theory for American readers (Holm 1997a) and in my text book Människans symboliska verklighetsbygge (People's Symbolic Construction of Reality, Holm 1997b), I could take the human symbolic capacity as my starting point and describe expressions and forms of religion as symbols located both in the inner existential space of people as well as in their outer existential space, in culture in general. I could then formulate a theoretical approach called integrated role theory, which is a further development of Hjalmar Sundén's role theory. I called his way of analysing experiences a perceptual theory, and combined it with certain deep psychological insights, which mean that we must also consider processes in the human psyche where memories and experiences are treated on an individual level. A combination of socially provided symbolic forms as well as of those that individuals develop within themselves, create the prerequisites for religious and spiritual experiences (see also Illman 2004).

By symbols I mean not only the concrete forms of expression in sounds and images, but, above all, the great thought-constructions such as god/devil, heaven/hell, angels/demons, and other phenomena in the world of religion. I also include the ritual forms in relation to rites of passage such as birth, puberty, marriage and burial, and others connected to celebrations, devotions and services. These great symbols are primarily conveyed in churches and societies, by established religions and sects; in other words by the socially provided structures. What I find important, however, is that as persons grow up, and also later in life, they learn to share these structures, but they also add their own experiences, which they gather in their memory and in their whole mental apparatus. At each repeated experiential event, the participants attach their own cognitive and emotional memories from their inner existential space to the thought-constructions and rituals, which, in many cases, make these alive and meaningful for the individuals. In other cases, however, they might be encumbering and negative. This entire process is, of course, dependent on the way in which the individual has learnt the thought-constructions and the rituals connected to them. If the learning process is positive, the symbolic language of religion gains an ability to emphasize and interpret the inner nature of life in a rewarding and signifying way. If, on the other hand, something goes wrong, the religious symbols gain a negative meaning and are experienced as an obstacle for spiritual development. The same is naturally true 
of symbols expressed in general forms of culture, in literature, art and music, which modern humans have by no means lost the ability to appreciate.

\section{Concluding remarks}

We can see that research, in which I, too, to a certain extent have participated, has developed our use of concepts, so that the term mysticism today covers large experiential areas. These can be intensive experiences of religious masters in various religions, or also qualities of the experiences of ordinary people today. Research on religion has also pointed to the fact that there is a kind of spirituality apart from that which the traditional religions have provided. This rather imprecise spirituality is something that comes close to general mysticism. The concepts of mysticism and spirituality have thus gained a much more extensive use during the last few years, and they now capture spiritual experience on a popular level. Spirituality provides forms of expression, for example, for the anxiety about the destruction of our planet, for needs and opportunities created by globalisation, for issues of peace and intercultural understanding, for experiences of art and music, and so on. What all this will entail for the fields of education and philosophy of life remains to be seen. But interesting perspectives on the teaching of religion do open up on the basis of research on modern spirituality.

On the theoretical level, a re-emergence of the biological and cognitive theories has taken place, which sometimes has led to very narrow interpretations. Nevertheless, a sobering up seems to have happened among representatives of cognitivism, so that socio-psychological and cultural perspectives are also again taken into consideration. In my view, various theoretical perspectives should always be balanced, in order for us to gain as complete an understanding as possible of humans as religious and spiritual beings.

\section{References}

\section{Andresen, Jensine}

2001 Introduction: towards a Cognitive Science of Religion. In: Jensine Andersen, Religion in Mind. Cognitive Perspectives on Religious Belief, Ritual, and Experience; pp. 7-16. Cambridge: Cambridge University Press.

\section{Barnard, G. William}

1997 Exploring Unseen Worlds. William James and the Philosophy of Mysticism. New York: State University of New York Press. 


\section{Geels, Antoon}

2002 Berusad av gud. Natur och Kultur.

\section{Holm, Nils G.}

1974 Glossolalins kulturmönster och ljudstruktur undersökta på ett material insamlat $i$ Svenskfinland. Lund. (Uttryck, kommunikation, religion, 2:2)

1975 Ritualistic Pattern and Sound Structure of Glossolalia in Material Collected in the Swedish-speaking Parts of Finland. Temenos 11: 43-6o.

1976 Tungotal och andedop. En religionspsykologisk undersökning av glossolali hos finlandssvenska pingstvänner. Diss. Uppsala: Acta Universitatis Upsaliensis. (Psychologia Religionum, 5)

1978 Pingströrelsen. En religionsvetenskaplig studies av pingströrelsen i Svenskfinland. Åbo: Research Institute of the Åbo Akademi Foundation.

1979 Mystik och intensiva upplevelser. Åbo: Research Institute of the Åbo Akademi Foundation.

1982a Ecstasy Research in the $20^{\text {th }}$ Century - An Introduction. In: Nils G. Holm (ed.), Religious Ecstasy. Stockholm: Almqvist \& Wiksell International. (Scripta Instituti Donneriani Aboensis, 11)

1982b Mysticism and Intense Experiences. Journal for the Scientific Study of Religion 21 (3): 268-76.

1997a An Integrated Role Theory for the Psychology of Religion: Concepts and Perspectives. In: Bernard Spilka \& Daniel N. McIntosh (eds), The Psychology of Religion. Theoretical Approaches. Boulder, CO: Westview Press.

1997b Männsikans symboliska verklighetsbygge: en psykofenomenologisk studie. Åbo: Åbo Akademi.

\section{Hood, Ralph W., Jr}

2006 The Common Core Thesis in the Study of Mysticism. In: Patrick McNamara (ed.), Where God and Science Meet. How Brain and Evolutionary Studies Alter Our Understanding of Religion. Vol. 3: The Psychology of Religious Experience; pp. 125-35. London: Praeger. (The Psychology of Religious Experience, 3)

\section{Illman, Ruth}

2004 Gränser och gränsöverskidanden. Skildarade erfarenheter av kulturella möten i internationellt projektarbete. Åbo: Åbo Akademi University Press.

\section{Jones, Richard, $\mathrm{H}$.}

1993 Mysticism Examined. Philosophical Inquiries into Mysticism. New York: State University of New York Press.

\section{Pyysiäinen, Ilkka}

2006 Amazing Grace: Religion and the Evolution of the Human Mind. In: Patrick McNamara (ed.), Where God and Science Meet. How Brain and Evolutionary Studies Alter Our Understanding of Religion. Vol. 1: Evolution, Genes, and the Religious Brain. London: Praeger.

\section{Stenqvist, Catharina}

1984 Simone Weil om livets tragik - och dess skönhet. Stockholm: Proprius förlag. 


\section{Mysticism ANd Spirituality}

1994 Förundran och förändring. Mystikens teori och livssyn. Förlagshuset ÅSAK.

\section{Taylor, Eugene}

1983 William James on Exceptional Mental States. New York: Charles Scribner's Sons. (The 1896 Lowell lectures)

\section{Tirri, Kirsi}

2004 Spiritualiteetti uskontokasvatuksessa. In: Lassi Larjo (ed.), Teologian uudet virtaukset; pp. 132-42. Helsinki: Suomalainen teologinen kirjallisuusseura.

\section{Ubani, Martin}

2007 Young, Gifted and Spiritual - the Case of Finnish Sixth-grade Pupils. Helsinki: University of Helsinki. (Research Report, 278)

Whitehouse, Harvey \& Robert N. McCauley

2005 Mind and Religion. Psychological and Cognitive Foundations of Religiosity. Walnut Creek: Altamira Press. 